\title{
Ketoconazole Blocks Bile Acid Synthesis in Hepatocyte Monolayer Cultures and In Vivo in Rat by Inhibiting Cholesterol $7 \alpha$-Hydroxylase
}

\author{
Hans M. G. Princen, Christine M. G. Huijsmans, Folkert Kuipers, „ Roel J. Vonk, ${ }^{*}$ and Herman Jan M. Kempen \\ TNO Gaubius Institute for Cardiovascular Research, 2313 AD Leiden; *Department of Pediatrics, \\ University of Groningen, $9712 \mathrm{KZ}$ Groningen, The Netherlands
}

\begin{abstract}
In cultured hepatocytes conversion of $\left[4-{ }^{14} \mathrm{C}\right]$ cholesterol into bile acids was dose dependently reduced by the antimycotic drug ketoconazole, giving half-maximal inhibition at $10 \mu \mathrm{M}$ ketoconazole in rat hepatocytes and at $1 \mu \mathrm{M}$ in human hepatocytes. No change was observed in the ratio of produced cholic, $\beta$-muricholic, and chenodeoxycholic acid with increasing amounts of the drug. Conversion of $\left[4-{ }^{14} \mathrm{C}\right] 7 \alpha$-hydroxycholesterol, an intermediate of bile acid pathway, to bile acids was not affected by ketoconazole. These results together with kinetic studies with rat liver microsomes, demonstrating noncompetitive inhibition $\left(K_{i}=0.4 \mu \mathrm{M}\right)$, indicate that cholesterol $7 \alpha$-hydroxylase is the main site of inhibition.

In bile-diverted rats a single dose of ketoconazole $(50 \mathrm{mg} /$ kg) dramatically impaired bile flow and biliary bile acid output (92\% inhibition). A similar blockade was observed using [4${ }^{14} \mathrm{C}$ cholesterol as precursor for bile acid synthesis. Therefore, treatment of patients with this drug may inhibit bile acid synthesis, resulting in a reduction of the bile acid pool size after long-term ketoconazole therapy.
\end{abstract}

\section{Introduction}

Ketoconazole is an orally active imidazole derivative and antimycotic agent with minimal toxicity, effective against a wide range of fungal pathogens (1). Its principal action is based on inhibition of the cytochrome P-450-mediated $14 \alpha$-demethylation of lanosterol in ergosterol synthesis in fungi at low concentrations. Much higher concentrations of the drug are required to inhibit conversion of lanosterol to cholesterol in man (2), rat (3), and in cultured lymphocytes (4) and Hep G2 cells (5). However, the last few years several side effects have been reported. Long-term ketoconazole therapy increased serum triglyceride levels in humans (6). Gynecomastia was observed in a few patients (7), as a result of interference of the drug with testosterone synthesis by inhibition of the $\mathrm{C}_{17-20}$ lyase $(8,9)$. Moreover, ketoconazole blocked adrenal steroidogenesis $(10,11)$ by inhibiting adrenal mitochondrial P450-dependent enzymes (11-hydroxylase of deoxycorticosterone and side chain cleavage of cholesterol) (11). In addition, these investigators found that a kidney

Presented in part at the 5th International Conference on Biochemistry, Biophysics, and Induction of Cytochrome P-450, in Budapest, Hungary, 1985.

Address reprint requests to Dr. Princen.

Received for publication 21 January 1986.

J. Clin. Invest.

(c) The American Society for Clinical Investigation, Inc.

0021-9738/86/10/1064/08 $\$ 1.00$

Volume 78, October 1986, 1064-1071 mitochondrial P-450 enzyme was blocked and they suggested that the drug may be a general inhibitor of mitochondrial P-450 enzymes (11). Recently, however, ketoconazole has also been shown to be a potent inhibitor of drug $N$-demethylase and $O$ deethylase activity in liver microsomes from rats $(12,13)$. Similar effects were observed on hepatic oxidative drug metabolism in humans (14).

In the light of the effects of ketoconazole on sterol synthesis, we studied the effect of this compound on bile acid synthesis, in which several cytochrome P-450-dependent enzymes are involved (15). This study demonstrates that ketoconazole inhibits bile acid synthesis in cultured human and rat hepatocytes. The reduced synthesis was the result of potent inhibition of the ratelimiting enzyme in the pathway of bile acid synthesis, cholesterol $7 \alpha$-hydroxylase (16). This enzyme, localized in microsomes, also belongs to the class of cytochrome P-450 enzymes (16).

In in vivo experiments, performed in rats with chronic total bile diversion $(17,18)$, ketoconazole administration caused a dramatic effect on bile flow and biliary bile acid output.

\section{Methods}

Materials and animals. Ketoconazole was obtained from Janssen Life Sciences Products, Beerse, Belgium. $\left[4-{ }^{14} \mathrm{C}\right] \mathrm{Cholesterol}(60 \mathrm{mCi} / \mathrm{mmol})$, $\left[{ }^{3} \mathrm{H}(\mathrm{G})\right]$ taurocholic acid $(6.6 \mathrm{Ci} / \mathrm{mmol})$ and $\left[24-{ }^{14} \mathrm{C}\right]$ taurocholic acid $(59$ $\mathrm{mCi} / \mathrm{mmol}$ ) were purchased from New England Nuclear (Boston, MA). Williams E culture medium and fetal bovine serum were from Flow Laboratories, Irvine, Scotland. Collagenase type I, soybean trypsin inhibitor, bovine serum albumin, choloylglycine hydrolase, pyruvic acid, dithiothreitol (DTT), ${ }^{1}$ butylated hydroxytoluene (BHT), Tween 80, and EGTA were obtained from Sigma Chemicals (St. Louis, MO). Cholic acid $(3 \alpha, 7 \alpha, 12 \alpha$-trihydroxy-5 $\beta$-cholanoic acid), chenodeoxycholic acid ( $3 \alpha, 7 \alpha$,dihydroxy-5 $\beta$-cholanoic acid) and $7 \alpha$ - and $7 \beta$-hydroxycholesterol were from Steraloids (Wilton, NH). Glucose-6-phosphate, NADP, glucose-6-phosphate dehydrogenase, NADH and lactate dehydrogenase (from rabbit muscle) were purchased from Boehringer (Mannheim, FRG). Insulin (Actrapid, $40 \mathrm{IU} / \mathrm{ml}$ ) was from Novo Industri (Copenhagen, Denmark) and dexamethasone from Organon (Oradexon, $5 \mathrm{mg} / \mathrm{ml}$, Oss, The Netherlands). Trypan blue was from BDH Chemicals (Poole, Dorset, England). Cholesterol, Hepes, thin-layer chromatography (TLC)-precoated silica gel 60 plates and all salts and solvents were obtained from E. Merck (Darmstadt, FRG). $\beta$-Muricholic acid ( $3 \alpha, 6 \beta, 7 \beta$-trihydroxy$5 \beta$-cholanoic acid) was prepared from bile of bile-diverted rats after extraction (19) and deconjugation with potassium hydroxide, as described (20).

$\left[4-{ }^{14} \mathrm{C}\right] 7 \alpha$-Hydroxycholesterol was biosynthesized in the cholesterol $7 \alpha$-hydroxylase assay by performing eight parallel incubations for 90 min with microsomes ( $1.5 \mathrm{mg}$ protein) from rats kept on a reversed lightdark cycle for 3 wk and fed $4 \%$ cholestyramine during the last week. Cholesterol $7 \alpha$-hydroxylase activity of these microsomes was 10 -fold

1. Abbreviations used in this paper: BHT, butylated hydroxytoluene; DTT, dithiothreitol; $\mathbf{K}_{\mathbf{i}}$, inhibitor constant; TLC, thin-layer chromatography. 
control value; yield of $\left[{ }^{14} \mathrm{C}\right] 7 \alpha$-hydroxycholesterol after extraction and TLC was $5.6 \%$ of added $\left[4-{ }^{14} \mathrm{C}\right]$ cholesterol $(10 \mu \mathrm{Ci})$. In these experiments no unlabeled exogenous cholesterol was added to the incubation mixture.

Male Wistar rats $200-300 \mathrm{~g}$ (250-300 g for hepatocyte isolation) were used throughout and maintained on standard chow (Hope Farms, Woerden, The Netherlands) and water ad lib. For preparation of hepatocytes and microsomes animals were killed between 9 and 10 a.m.

Rat hepatocyte preparation and culture. Rat liver cells were isolated by perfusion with $0.05 \%$ collagenase and $0.005 \%$ trypsin inhibitor as described previously (21). Viability, as determined by trypan blue exclusion, was higher than $90 \%$. The cells were seeded on 100 -mm diameter plastic tissue culture dishes or 6-well cluster plates (35-mm diam, Costar, Cambridge, MA) at a density of $1 \times 10^{5} \mathrm{cells} / \mathrm{cm}^{2}$ and were maintained in Williams $\mathrm{E}$ medium (22) supplemented with $10 \%$ heat-inactivated fetal bovine serum, $2 \mathrm{mM}$ L-glutamine, $20 \mathrm{mU} / \mathrm{ml}$ insulin, $50 \mathrm{nM}$ dexamethasone, $100 \mathrm{IU} / \mathrm{ml}$ penicillin, and $100 \mu \mathrm{g} / \mathrm{ml}$ streptomycin at $37^{\circ} \mathrm{C}$ in a $5 \% \mathrm{CO}_{2} / 95 \%$ air atmosphere. After a 4 -h attachment period medium was refreshed with $5 \mathrm{ml}$ (dishes) or $1 \mathrm{ml}$ (wells) of culture medium and $\left[4-{ }^{14} \mathrm{C}\right]$ cholesterol or $\left[4{ }^{14} \mathrm{C}\right] 7 \alpha$-hydroxycholesterol was added, solubilized in fetal bovine serum. After a 24-h incubation period with 0 to $20 \mu \mathrm{M}$ ketoconazole, viability was determined. Cells at all concentrations were viable, as judged by trypan blue exclusion ( $>95 \%$ ) and leakage of the cytoplasmic enzyme lactate dehydrogenase to the culture medium. Lactate dehydrogenase activity (determined as described in ref. 23) in culture medium was $10 \%$ of cellular content, in agreement with others $(24,25)$, and not significantly different with addition of $20 \mu \mathrm{M}$ ketoconazole.

Human hepatocytes. Human hepatocytes were isolated from a piece of liver tissue, essentially as described before (26). After informed consent of relatives was obtained, the liver was taken during routine human donor nephrectomy from a physically healthy 39 -yr-old male who died after severe traumatic brain injury. Immediately after kidney removal, a 200-g segment of liver tissue was excised and immersed in a cold buffer containing $10 \mathrm{mM}$ Hepes, $\mathrm{pH} 7.4,142 \mathrm{mM} \mathrm{NaCl}, 6.7 \mathrm{mM} \mathrm{KCl}$, and $0.5 \mathrm{mM}$ EGTA. The liver was transported to the perfusion site within $30 \mathrm{~min}$, and perfusion with 1 liter of this buffer at a rate of $40 \mathrm{ml} / \mathrm{min}$ was started after insertion of four polyethylene catheters (18 gauge) in vascular orifices that could be identified at the cut surface. After the preperfusion the liver was perfused successively with $100 \mathrm{ml}$ of a Hepes buffer (pH 7.6) without recirculation, and $250 \mathrm{ml}$ of this buffer containing $0.05 \%$ collagenase with recirculation for $20 \mathrm{~min}$. Liver tissue was dissociated in Hanks' buffer containing $2 \%$ bovine serum albumin, cells were filtered through a $250-\mu \mathrm{m}$ filter, centrifuged ( $75 \mathrm{~g}$ for $5 \mathrm{~min}$ ), and washed three times in cold culture medium to remove damaged and nonparenchymal cells. After counting and testing for trypan blue exclusion (viability was 78\%), hepatocytes were plated at a density of 1.25 $\times 10^{5} \mathrm{cells} / \mathrm{cm}^{2}$ and cultured as described for rat hepatocytes. The medium was renewed after $6 \mathrm{~h}$ and every $24 \mathrm{~h}$ thereafter.

Bile acid synthesis in cultured hepatocytes. After 7, 17, or $24 \mathrm{~h}$ incubation with $\left[4-{ }^{14} \mathrm{C}\right]$ cholesterol cells and media from rat hepatocyte cultures were harvested and bile acids were extracted using a reversephase cartridge (Sep-pak C-18, Waters Associates, Milford, MA) with $\left[{ }^{3} \mathrm{H}(\mathrm{G})\right]$ taurocholic acid as recovery standard essentially as in (27). Bile acids were deconjugated using choloylglycine hydrolase and after extraction separated on a thin layer of silica. The plates were developed in toluene/dioxane/glacial acetic acid 20:10:2; vertical edges were colored in iodine vapor to visualize reference bile acids or plates were autoradiographed after spraying with Enhance (New England Nuclear, Boston, MA). Areas containing bile acids were scraped off and counted using a double-label program. Bile acid markers used with their retardation factor $\left(R_{F}\right)$-values were cholic acid $(0.22), \beta$-muricholic acid $(0.30)$, and chenodeoxycholic acid (0.48). Recovery of uniformly labeled $\left[{ }^{3} \mathrm{H}(\mathrm{G})\right]$ taurocholate, after correction of $14 \%$ loss of radioactivity by deconjugation, was $75-95 \%$, depending on the amount of protein in the sample. In medium and cells from human hepatocyte cultures (cultured from 42 to $66 \mathrm{~h}$ after plating) radioactivity was determined in cholic and chenodeoxycholic acid, known to be the major primary bile acids in man $(28,29)$.

Preparation of microsomes. Animals were anesthetized with Nem- butal (Ceva, Paris, France). Livers were perfused in situ and homogenized in an ice-cold buffer containing $100 \mathrm{mM}$ sucrose, $40 \mathrm{mM}$ potassium phosphate, $\mathrm{pH} 7.4,50 \mathrm{mM}$ potassium fluoride, $2 \mathrm{mM}$ EDTA, and 5 mM DTT. All subsequent procedures were performed at $4^{\circ} \mathrm{C}$. After centrifugation at $16,000 \mathrm{~g}$ for $20 \mathrm{~min}$, microsomes were isolated by centrifugation of the supernatant for $1 \mathrm{~h}$ at $100,000 \mathrm{~g}$. Microsomes were washed once in the same buffer without potassium fluoride and with $100 \mathrm{mM}$ potassium phosphate, $\mathrm{pH} 7.4$, resuspended in this last buffer at $15-25 \mathrm{mg} / \mathrm{ml}$, frozen in liquid nitrogen in small portions, and stored at $-80^{\circ} \mathrm{C}$. Microsomal protein and cholesterol were determined according to Lowry et al. (30) and Gamble et al. (31), respectively.

Cholesterol $7 \alpha$-hydroxylase assay. Cholesterol $7 \alpha$-hydroxylase was measured as previously described (32) with minor modifications. Microsomes $(0.5 \mathrm{mg}$ protein) in duplicates were preincubated for $10 \mathrm{~min}$ at $37^{\circ} \mathrm{C}$ in a medium containing $50 \mathrm{mM}$ potassium phosphate, $\mathrm{pH} 7.4$, $2 \mathrm{mM}$ DTT, $100 \mu \mathrm{M}\left[4-{ }^{14} \mathrm{C}\right]$ cholesterol $(0.5 \mu \mathrm{Ci}$, purified before use) and $1.5 \mathrm{mg} / \mathrm{ml}$ Tween 80 . Enzyme activity at the end of the preincubation time was assayed by addition of a NADPH regenerating system containing $20 \mathrm{mM}$ glucose 6-phosphate, $2 \mathrm{mM}$ NADP, $4 \mathrm{mM} \mathrm{MgCl}_{2}$, and $1.4 \mathrm{IU}$ glucose-6-phosphate dehydrogenase to a final volume of $1.0 \mathrm{ml}$. After $30 \mathrm{~min}$ at $37^{\circ} \mathrm{C}$ in a shaking water bath the reaction was stopped by addition of $10 \mathrm{ml}$ chloroform/methanol 2:1 containing $0.01 \%$ BHT. The organic layer was washed with $2 \mathrm{ml} 0.9 \% \mathrm{NaCl}$ and evaporated. The residue, together with $7 \alpha$ - and $7 \beta$-hydroxycholesterol and cholesterol as markers, was applied to a thin layer of silica, which was twice developed with benzene/ethylacetate 2:3. $7 \alpha$-Hydroxycholesterol and cholesterol, were visualized with rhodamine $6 \mathrm{~B}$ or autoradiography, scraped off, and counted. Blank values, determined by running parallel incubations without a NADPH generating system, were subtracted before calculating enzyme activity. Formation of $7 \alpha$-hydroxycholesterol was linear for at least $90 \mathrm{~min}$ and up to $1.5 \mathrm{mg}$ added microsomal protein. Unless otherwise indicated ketoconazole $(20 \mu \mathrm{l})$ was added dissolved in $50 \mathrm{mM}$ $\mathrm{HCl}-1.5 \mathrm{mg} / \mathrm{ml}$ Tween 80 .

In vivo experiments. Male Wistar rats $(275-300 \mathrm{~g})$ were housed individually in plexiglass cages in a temperature- and light-controlled room (temperature $20^{\circ} \mathrm{C}$; lights on between 7 a.m. and 7 p.m.).

Rats were equipped with permanent silicon catheters in the bile duct, the duodenum, and the heart as described earlier (18). These catheters were tunneled subcutaneously and fixed to the skull, providing the opportunity either to return bile back to the animal via the duodenal catheter (closed enterohepatic circulation), or to drain the bile outside the cage (bile diversion). During bile diversion, bile was led through a polyethylene tubing with a swivel joint, thus permitting free movement to the rats, and allowing bile excretion to be studied in conscious and unrestrained animals. The heart catheter allowed intracardial administration as well as repeated blood sampling without additional stress to the animals (33). Experiments were performed after $8 \mathrm{~d}$ of biliary drainage, i.e., after establishment of a new steady state in bile acid synthesis (18). At 12 a.m. on the day of the experiment a single dose $(50 \mathrm{mg} / \mathrm{kg}$ body wt) of ketoconazole in $50 \mathrm{mM} \mathrm{HCl}$ or an equivalent amount of solvent was injected via the duodenal catheter. During these experiments bile was collected continuously for $26 \mathrm{~h}$ after ketoconazole administration in tared test tubes in 2-h fractions, using a fraction collector. Before the experiment two fractions were collected to assess baseline rates of bile flow and biliary bile acid and cholesterol output. No difference was observed in food intake and body weight between ketoconazole-treated and control animals during the experiments.

In some experiments rat serum labeled with $\left[4-{ }^{14} \mathrm{C}\right]$ cholesterol was injected intracardially $2 \mathrm{~h}$ after ketoconazole administration. For this purpose serum from a donor rat was incubated with $\left[{ }^{14} \mathrm{C}\right]$ cholesterol (34), leading predominantly to association of radioactivity with the two high density lipoprotein subfractions in rat serum. All rats received 0.75 $\mathrm{ml}$ of serum containing $0.5 \mu \mathrm{Ci}\left[4-{ }^{14} \mathrm{C}\right]$ cholesterol as a bolus injection, whereas blood samples of $0.15 \mathrm{ml}$ were taken at $5,10,15$, and $30 \mathrm{~min}$ and $1,2,3,6,12$, and $24 \mathrm{~h}$ after injection. Blood was immediately transferred to heparinized tubes and centrifuged $(10 \mathrm{~min}, 3,500 \mathrm{~g})$. Bile and plasma samples were stored at $-20^{\circ} \mathrm{C}$ until analysis.

In another set of experiments ketoconazole was given to rats via the 
duodenal catheter $3 \mathrm{~h}$ before intracardial administration of $0.25 \mu \mathrm{Ci}$ [24${ }^{14} \mathrm{C}$ ]taurocholic acid in saline. Bile was collected during $1.5 \mathrm{~h}$ in 15 -min fractions.

Chemical analysis and calculations. Biliary bile acid concentration was measured using an enzymatic fluorimetric assay (Sterognost-Flu, Nyegaard, Oslo, Norway). Cholesterol concentrations in bile were determined after lipid extraction (19) according to Gamble et al. (31). Radioactivity in bile, after decolorization with an equal volume of $\mathrm{H}_{2} \mathrm{O}_{2}$, and plasma was measured in $50-\mu \mathrm{l}$ aliquots by scintillation counting using an external standardization method. To distinguish between radiolabeled cholesterol and bile acids in bile, $50-\mu$ l portions were extracted (19), and radioactivity in the chloroform (cholesterol) and methanolwater phase (bile acids) was determined.

Biliary excretion rates of bile acids and cholesterol were calculated by multiplying bile flow by biliary concentration, the latter corrected for the dead space of the bile catheter. Excretion rates after the drug or acid injection (averaged per $2 \mathrm{~h}$ ) were expressed in percentage of the baseline value in the last $4 \mathrm{~h}$ before administration. Statistical significance of differences was calculated using Student's $t$ test for unpaired data (35) with the level of significance selected to be $P<0.05$. Values were expressed as mean $\pm \mathrm{SD}$

\section{Results}

Synthesis of bile acids by cultures of rat hepatocyte monolayers. To avoid the influence of inhibition of cholesterol synthesis (by blocking $14 \alpha$-demethylation of lanosterol) on bile acid synthesis from de novo synthesized cholesterol, we used $\left[{ }^{14} \mathrm{C}\right]$ cholesterol as substrate for measuring bile acid synthesis. Fig. 1 shows the time course of bile acid synthesis over the 24 -h period (4 to 28 $\mathrm{h}$ after plating), in which we studied the effect of ketoconazole on synthesis of bile acids by rat hepatocytes in monolayer culture. Cholic acid comprised 55\% of total bile acid synthesis (considered to be the sum of all separately determined bile acids in medium and in cells) after $24 \mathrm{~h}$ of incubation, whereas chenodeoxycholic acid was only $\sim 10 \%$ during the incubation period. At the three time points in this period $68-80 \%$ of total synthesized bile acids were found intracellularly. However, no specific retention of one of the three individual bile acids (cholic acid, $\beta$-muricholic acid, and chenodeoxycholic acid) in the cell was observed.

Effect of ketoconazole on bile acid synthesis by rat and human hepatocytes. To exclude the possibility that ketoconazole blocked the uptake of cholesterol by the hepatocytes, we measured [4 ${ }^{14} \mathrm{C}$ ]cholesterol absorption by the cells during the 24- $\mathrm{h}$ incubation period with different concentrations of this drug. Approximately $3 \%$ of added $\left[{ }^{14} \mathrm{C}\right]$ cholesterol per milligram cell protein was absorbed by the hepatocytes and no difference in $\left[4-{ }^{14} \mathrm{C}\right]$ cholesterol uptake was found with 0,5 , and $20 \mu \mathrm{M}$ ketoconazole. The total amount of radioactivity incorporated in bile acids in the absence of ketoconazole amounted to $3.5 \%$ of total $\left[{ }^{14} \mathrm{C}\right]$ cholesterol present in the hepatocytes after $24 \mathrm{~h}$ of incubation. This last finding indicates that only a minor portion of added $\left[4-{ }^{14} \mathrm{C}\right]$ cholesterol is converted to bile acids.

Addition of ketoconazole to monolayer cultures of rat hepatocytes caused a dose-dependent reduction of total bile acid synthesis by these cells (Fig. 2). No significant change was observed in the ratio of produced cholic acid $(58 \pm 4 \%$ of total bile acid synthesis), $\beta$-muricholic acid $(33 \pm 5 \%)$ and chenodeoxycholic acid $(9 \pm 1 \%)$ with increasing amounts of ketoconazole. In contrast, there was a significant difference $(P<0.05)$ between bile acids associated with cells at $0,1,5$, and $10 \mu \mathrm{M}$ ketoconazole $(75 \pm 3 \%, 76 \pm 7 \%, 76 \pm 7 \%$, and $72 \pm 1 \%$ of total intracellular and extracellular bile acids, respectively) and at a concentration of $20 \mu \mathrm{M}(60 \pm 5 \%$ of total bile acid synthesis). In these experiments no specific bile acid was retained by the hepatocytes.

A concentration as low as $5 \mu \mathrm{M}$ ketoconazole inhibited bile acid synthesis in rat hepatocytes, whereas half-maximal inhibition ( $\left.\mathrm{I}_{50}\right)$ was achieved at $10 \mu \mathrm{M}$ (Fig. 3). A similar blockade of bile acid synthesis by ketoconazole was observed with monolayer cultures of human hepatocytes. However, the $I_{50}$-value for bile acid synthesis by these human hepatocytes was approximately 10 -fold lower than that found for rat hepatocytes.

Since cholesterol $7 \alpha$-hydroxylase is the first enzyme in the bile acid synthesis pathway and believed to be the regulatory step (16), it was interesting to study the influence of ketoconazole on conversion of $7 \alpha$-hydroxycholesterol into bile acids by rat hepatocyte monolayers. It has been shown previously that exogenous $7 \alpha$-hydroxycholesterol is metabolized to bile acids (36, 37). The data presented in Table I demonstrate that $>85 \%$ of the added $\left[{ }^{14} \mathrm{C}\right] 7 \alpha$-hydroxycholesterol was converted into bile acids. Furthermore, in contrast with synthesis of bile acids from $\left[4-{ }^{14} \mathrm{C}\right]$ cholesterol ketoconazole did not significantly inhibit bile

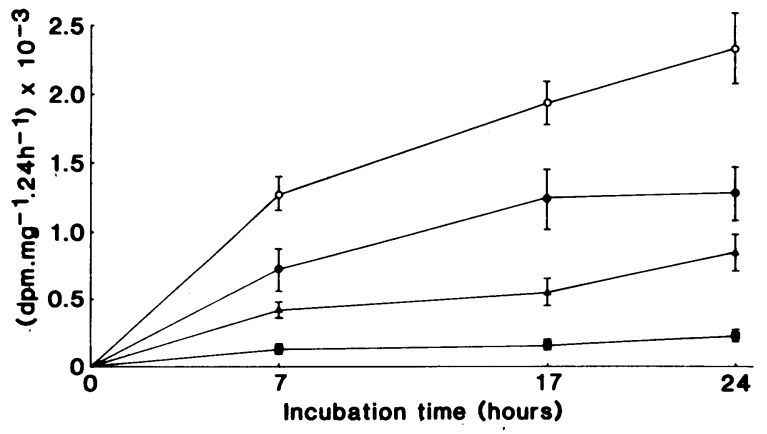

Figure 1. Time course of bile acid synthesis in rat hepatocytes. Hepatocytes were isolated and cultured as described in Methods. $4 \mathrm{~h}$ after cell seeding in $10 \mathrm{~cm}^{2}$-wells $0.15 \mu \mathrm{Ci}\left[4-{ }^{14} \mathrm{C}\right]$ cholesterol in culture medium was added. Cells and medium were harvested at indicated times, cells were washed four times after removal of medium and bile acids were determined. $\bullet$, cholic acid; $\Delta, \beta$-muricholic acid; $\boldsymbol{\sim}$, chenodeoxycholic acid; and $o$, total bile acids. The values shown represent the sum of intracellular and extracellular bile acids and are means $( \pm \mathrm{SD})$ of four experiments with duplicate incubations.

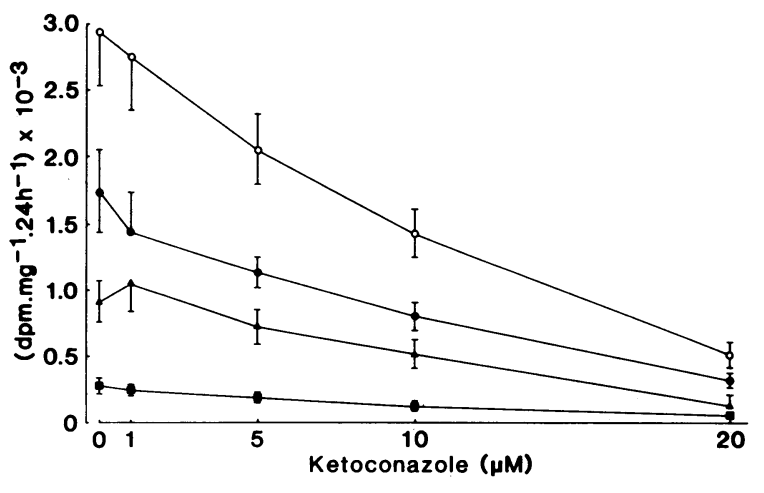

Figure 2. Inhibition of bile acid synthesis in rat hepatocytes by ketoconazole. $4 \mathrm{~h}$ after plating in 100-mm diameter tissue culture dishes, 1 $\mu \mathrm{Ci}\left[4-{ }^{14} \mathrm{C}\right]$ cholesterol in culture medium and $25 \mu \mathrm{l}$ of ketoconazole, dissolved in $50 \mathrm{mM} \mathrm{HCl}$, was added. After $24 \mathrm{~h}$ incubation radioactivity in intracellular and extracellular bile acids was determined. Symbols are as described in Fig. 1. Values shown are means ( \pm SD) of five experiments with duplicate incubations. 


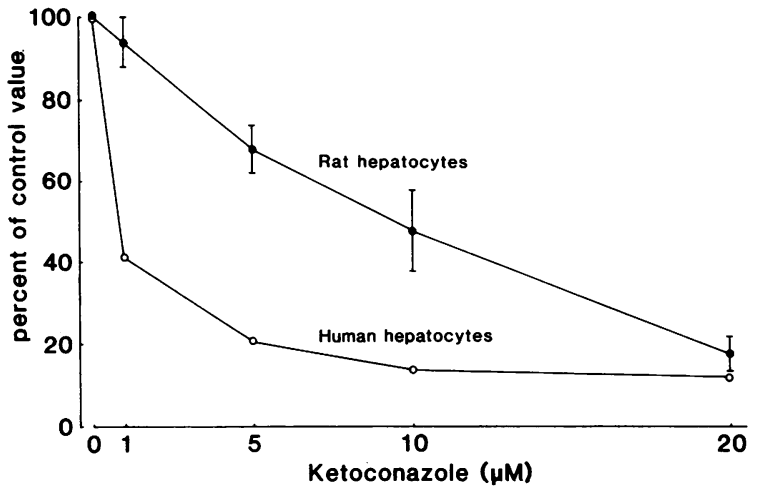

Figure 3. Effect of ketoconazole on bile acid synthesis by human and rat hepatocytes. Human hepatocytes were isolated and cultured as described in Methods. Inhibition by ketoconazole of cholic acid and chenodeoxycholic acid synthesis by human hepatocytes was measured during a 24-h incubation from 42 to $66 \mathrm{~h}$ after plating on $100-\mathrm{mm}$ diam tissue culture dishes. Ketoconazole and $\left[4-{ }^{14} \mathrm{C}\right]$ cholesterol were added as described in legend of Fig. 2. Radioactivity in bile acids was determined in medium and cells. Intracellular bile acids comprised $\sim 15 \%$ of total bile acids. Absolute synthesis of cholic and chenodeoxycholic acids in medium and cells without ketoconazole (100\% value) was $2195 \pm 263 \mathrm{dpm} \cdot \mathrm{mg}^{-1} \cdot 24 \mathrm{~h}^{-1}$, whereas cholic acid-chenodeoxycholic acid ratio was 55:45. For comparison values obtained from experiments with rat hepatocytes (Fig. 2) are shown.

acid synthesis from $\left[{ }^{14} \mathrm{C}\right] 7 \alpha$-hydroxycholesterol even at $20 \mu \mathrm{M}$ ketoconazole (see for comparison Fig. 3 and Table I).

Effect of ketoconazole on liver microsomal cholesterol $7 \alpha$ hydroxylase activity. The above-mentioned experiments with rat hepatocyte monolayer cultures suggest that inhibition of bile acid synthesis by this antimycotic agent takes place at the first and rate-limiting enzyme in bile acid synthesis pathway, cholesterol $7 \alpha$-hydroxylase. To confirm this finding, we incubated ketoconazole with microsomes prepared from rat liver. Addition of various concentrations of ketoconazole to the reaction mixture resulted in a strong inhibition of cholesterol $7 \alpha$-hydroxylase activity, giving 34,75 , and $94 \%$ inhibition at $0.2,2$, and $10 \mu \mathrm{M}$ ketoconazole, respectively, which was significantly different $(P$ $<0.05)$ from the control value without ketoconazole $(1.28 \pm 0.10$ $\mathrm{nmol} \cdot \mathrm{mg}^{-1} \cdot \mathrm{h}^{-1}$ ). A linear relationship between logarithmic concentration of the drug and inhibition of cholesterol $7 \alpha-$

Table I. Effect of Ketoconazole on Conversion of $7 \alpha-$ Hydroxycholesterol into Bile Acids by Rat Hepatocytes

\begin{tabular}{cl}
\hline Ketoconazole & Conversion of $7 \alpha$-hydroxycholesterol \\
\hline$\mu M$ & $\%$ \\
0 & $91 \pm 2$ \\
5 & $89 \pm 4$ \\
20 & $85 \pm 4$ \\
\hline
\end{tabular}

Hepatocytes were prepared and seeded as described in Methods. $\left[4-{ }^{14} \mathrm{C}\right] 7 \alpha$-hydroxycholesterol $6 \times 10^{3} \mathrm{dpm} /$ well together with fresh medium was added to $10 \mathrm{~cm}^{2}$-wells at $4 \mathrm{~h}$ after plating. Cells were incubated for $21 \mathrm{~h}$, medium and hepatocytes were harvested and extracted according to Bligh and Dyer (19). After phase separation, radioactivity in the methanol-water phase was determined and expressed as percentage conversion of total recovered disintegrations per minute. Values shown are means $( \pm S D)$ of four experiments with duplicate incubations.

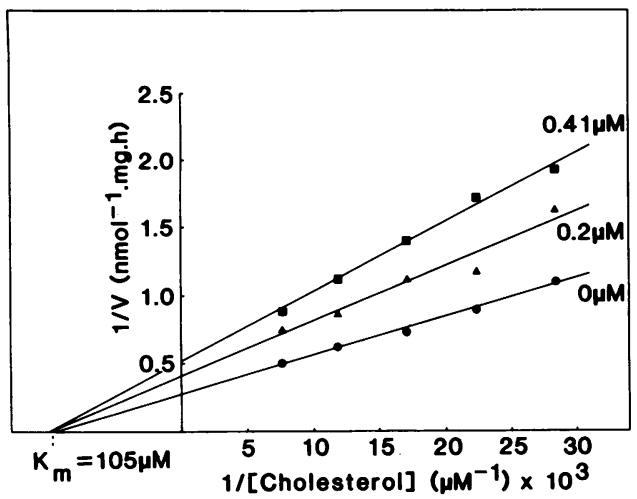

Figure 4. Lineweaver-Burk plots showing the inhibitory effects of ketoconazole on cholesterol $7 \alpha$-hydroxylase activity. Incubations were performed in the presence of $0.41 \mu \mathrm{M}(\bullet), 0.20 \mu \mathrm{M}(\Delta)$ or no (๑) ketoconazole. The figure shown is representative for three independent experiments with liver microsomes isolated from two rats.

hydroxylase was found, giving an $\mathrm{I}_{50}$-value of $0.4 \mu \mathrm{M}$. Kinetic studies were performed to determine the mechanism of inhibition of cholesterol $7 \alpha$-hydroxylase. As shown in Fig. 4, the fact that the apparent $K_{\mathrm{m}}$-value for the enzyme $(105 \mu \mathrm{M})$ was virtually unchanged in the presence of ketoconazole demonstrates noncompetitive inhibition. The Dixon plot in Fig. 5 confirms this finding, giving a $K_{\mathrm{i}}$-value for ketoconazole of $0.4 \mu \mathrm{M}$, comparable to the $\mathrm{I}_{50}$-value obtained with these microsomes and much lower than the apparent $K_{\mathrm{m}}$ for cholesterol, indicating that the drug has a strong affinity for the enzyme.

Effect of ketoconazole on biliary excretion of bile acids and cholesterol, and on bile flow in vivo. In vivo experiments were performed in rats to validate our findings obtained in monolayers of human and rat hepatocytes by ketoconazole. Rats with chronic total bile diversion (18) were used, since in these animals the bile acid pool is depleted and bile acid synthesis can be measured as biliary bile acid excretion. As demonstrated in Fig. 6 during long-term interruption of the enterohepatic circulation, both bile flow and biliary bile acid excretion displayed clear circadian variations, in agreement with a previous report (17). Administration of $50 \mathrm{mg} / \mathrm{kg}$ ketoconazole via the duodenal catheter led

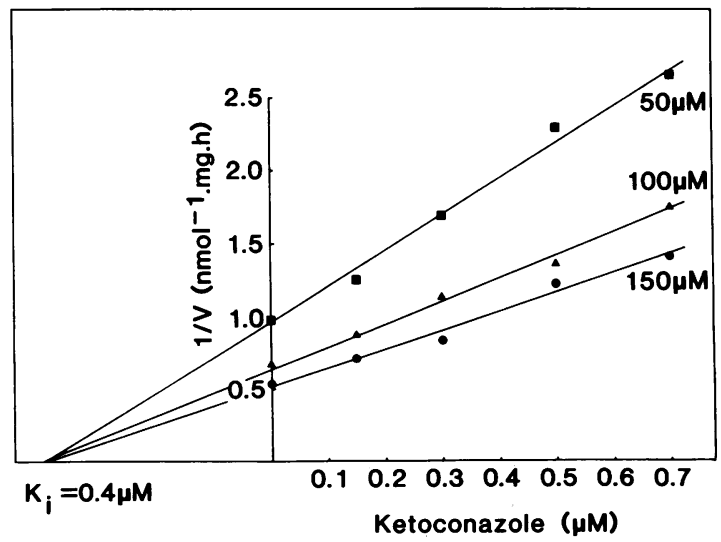

Figure 5. Dixon plots of the inhibition of cholesterol $7 \alpha$-hydroxylase by ketoconazole. Substrate concentrations were $50 \mu \mathrm{M}(\square), 100 \mu \mathrm{M}$ $(\triangleleft)$, and $150 \mu \mathrm{M}(\bullet)$ cholesterol. The figure shown is representative for three independent experiments with liver microsomes isolated from two rats. 


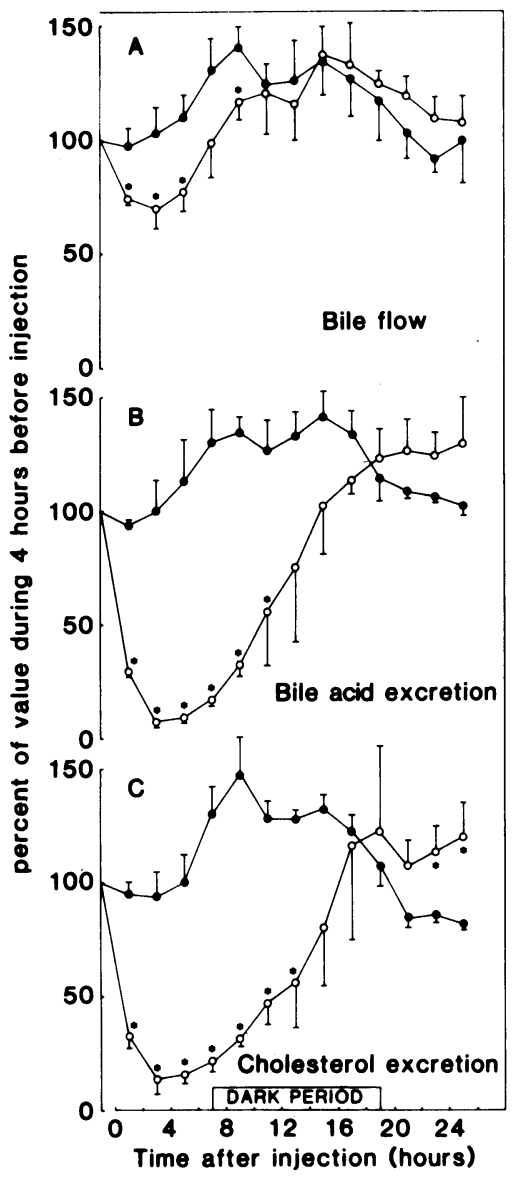

Figure 6. Effects of ketoconazole on bile flow $(A)$ and excretion rates of bile acids $(B)$ and cholesterol $(C)$ in bile-diverted rats. Rats were given $50 \mathrm{mM} \mathrm{HCl}(\bullet)$ or a solution of ketoconazole $(50 \mathrm{mg} / \mathrm{kg}$ body weight) in $50 \mathrm{mM} \mathrm{HCl}(O)$ via the duodenal catheter at $t=0(12$ a.m.). Bile collection was started $4 \mathrm{~h}$ before $t=0$. Rates for the $26 \mathrm{~h}$ after $t=0$ were expressed as percentage of their values in the last $4 \mathrm{~h}$ prior to injection, for each individual experiment. The values shown represent means $( \pm \mathrm{SD})$ of these percent values of experiments with three animals per group. A significant difference $(P<0.05)$ between ketoconazole-treated and control rats is indicated by an asterisk. Absolute values in the $4 \mathrm{~h}$ before injection (means $\pm \mathrm{SD}$ ) are

\begin{tabular}{llll}
\hline & & Excretion & \\
\cline { 3 - 4 } & Bile flow & Bile acids & Cholesterol \\
\hline & $\left(\mathrm{ml} \cdot \mathrm{h}^{-1}\right)$ & $\left(\mu \mathrm{mol} \cdot \mathrm{h}^{-1}\right)$ & $\left(\mu \mathrm{mol} \cdot \mathrm{h}^{-1}\right)$ \\
Control & $0.42 \pm 0.05$ & $11.3 \pm 3.4$ & $0.073 \pm 0.003$ \\
Ketoconazole & $0.49 \pm 0.02$ & $11.6 \pm 1.5$ & $0.070 \pm 0.003$
\end{tabular}

to a rapid decrease in bile flow, reaching its minimum value after 2 to $4 \mathrm{~h}$ (Fig. $6 \mathrm{~A}$ ). Bile acid and cholesterol excretion concomitantly declined dramatically to 8 and $15 \%$, respectively, of the baseline value in the last $4 \mathrm{~h}$ before injection (Fig. $6 \mathrm{~B}$ and $C$ ). Since in these bile-diverted animals bile acid output represents bile acid synthesis, we conclude that ketoconazole blocked synthesis of bile acids almost completely.

A similar inhibition of bile acid excretion in bile-diverted rats was observed at much lower doses of 5 and $10 \mathrm{mg} / \mathrm{kg}$, resulting in a significant decrease of biliary bile acid excretion to
63 and $32 \%$ of the control value after 2 to $4 \mathrm{~h}$, respectively. This reduction continued for a shorter time as compared with the effect found after $50 \mathrm{mg} / \mathrm{kg}$ (data not shown).

In order to check whether this fall in bile acid excretion was accomplished by a reduced supply of cholesterol by inhibition of cholesterol synthesis, we injected rat serum labeled with [4${ }^{14} \mathrm{C}$ ]cholesterol intracardially in ketoconazole-treated and control rats $2 \mathrm{~h}$ after administration of ketoconazole and solvent, respectively. No difference was observed in the distribution of radioactivity and disappearance from plasma in both groups (data not shown). However, ketoconazole inhibited excretion of ${ }^{14} \mathrm{C}$ radioactivity in bile during the period in which bile acid production was blocked (Fig. 7). Because more than $97 \%$ of total ${ }^{14} \mathrm{C}$-radioactivity is excreted as bile acids (Table II), inhibition of excretion of ${ }^{14} \mathrm{C}$-radioactivity must be caused by a diminished bile acid synthesis.

In order to test whether ketoconazole depressed bile acid output by blocking their transport across the canalicular membrane, a tracer dose of $\left[{ }^{14} \mathrm{C}\right]$ taurocholate was given intracardially $3 \mathrm{~h}$ after ketoconazole $(50 \mathrm{mg} / \mathrm{kg}$ ) administration. Bile was collected and radioactivity in bile determined. Recovery of ${ }^{14} \mathrm{C}$ radioactivity in bile $1 \mathrm{~h}$ after injection was $89.3 \pm 3.2 \%$ for control rats and $93.5 \pm 5.4 \%$ for drug-treated animals. This finding demonstrates that bile acid transport across both sinusoidal and canalicular membranes of hepatocytes is not appreciably hampered by ketoconazole.

\section{Discussion}

Monolayer cultures of rat hepatocytes were shown to synthesize bile acids from labeled precursor in a linear fashion between 4 and $28 \mathrm{~h}$ after plating (the period in which the effects of ketoconazole were studied, Fig. 1). Cholic acid comprised 55 to $65 \%$ of total synthesized bile acids during this time interval, a value in good agreement with cholic acid content in vivo $(38,39)$. On the other hand the ratio of $\beta$-muricholic to chenodeoxycholic acid was slightly increased as compared with the value in bile of whole animals (40). Similar cholic acid content in rat hepatocyte monolayer cultures was reported by Davis et al. (20). These authors, however, did not detect chenodeoxycholic acid,

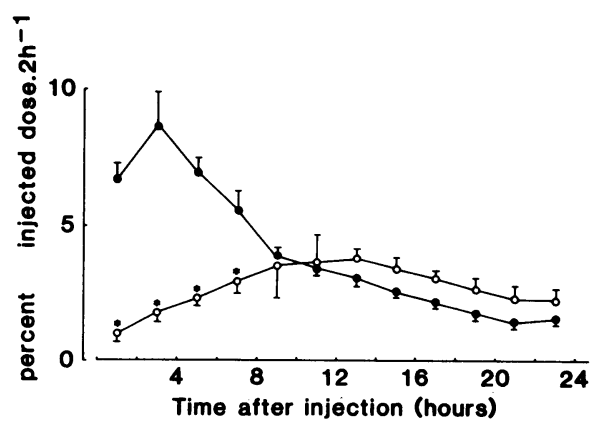

Figure 7. Effect of ketoconazole on biliary excretion of ${ }^{14} \mathrm{C}$-radioactivity after injection of serum-associated $\left[4-{ }^{14} \mathrm{C}\right]$ cholesterol. $2 \mathrm{~h}$ after administration of $50 \mathrm{mM} \mathrm{HCl}$ (control, $\bullet$ ) or $50 \mathrm{mg} / \mathrm{kg}$ ketoconazole (o) $0.75 \mathrm{ml}$ rat serum labeled with $\left[4-{ }^{14} \mathrm{C}\right]$ cholesterol $(0.5 \mu \mathrm{Ci} / \mathrm{rat})$ was injected via the heart catheter. Bile was collected and radioactivity in an aliquot was determined. Values are expressed as percentage of the injected dose and are means $( \pm S D)$ of experiments with three rats per group. A significant difference $(P<0.05)$ between control and ketoconazole-treated animals is indicated by asterisks. 
Table II. Recovery of ${ }^{14}$ C-Radioactivity in the Bile Acid and Cholesterol Fraction of Bile from Ketoconazole-treated and Control Rats

\begin{tabular}{|c|c|c|c|c|c|c|}
\hline \multirow[b]{3}{*}{ Experimental group } & \multicolumn{6}{|c|}{ Recovery of ${ }^{14} \mathrm{C}$-radioactivity as percentage of injected dose } \\
\hline & \multicolumn{3}{|c|}{ Time after injection $12 \mathrm{~h}$} & \multicolumn{3}{|l|}{$24 \mathrm{~h}$} \\
\hline & Bile acids & Cholesterol & Total & Bile acids & Cholesterol & Total \\
\hline Control & $35.2 \pm 3.4$ & $1.2 \pm 0.2$ & $36.7 \pm 2.9$ & $49.3 \pm 1.6$ & $1.6 \pm 0.4$ & $51.0 \pm 1.8$ \\
\hline Ketoconazole & $15.1 \pm 2.0^{*}$ & $0.5 \pm 0.1^{*}$ & $15.6 \pm 2.0^{*}$ & $32.6 \pm 1.8^{*}$ & $1.1 \pm 0.1$ & $33.4 \pm 1.9^{*}$ \\
\hline
\end{tabular}

$2 \mathrm{~h}$ after administration of solvent (control) or ketoconazole $\left(50 \mathrm{mg} / \mathrm{kg}\right.$ ) rat serum labeled with $\left[4-{ }^{14} \mathrm{C}\right]$ cholesterol was injected via the heart catheter into both groups. Bile was collected, an aliquot was extracted and radioactivity was determined in bile, and chloroform and methanol-water phase after extraction. Values shown are means $( \pm \mathrm{SD})$ of experiments with three rats per group. * Significant difference $(P<0.05)$ between control and ketoconazole-treated animals.

which was found to represent 10 to $15 \%$ of total bile acid synthesis by rat hepatocytes $(41,42)$. It has been suggested, that culture medium which contains insulin, as used by Davis et al. and in our experiments ( $135 \mathrm{nM}$ ), is responsible for the high cholic acid content by stimulating the $7 \alpha$-hydroxy-cholest-4-en-3-one $12 \alpha$ hydroxylase (42). This enzyme is thought to control the ratio of cholic acid to chenodeoxycholic plus $\beta$-muricholic acid (43). Approximately $75 \%$ of synthesized bile acids was found intracellularly during the 4 - to 28 -h incubation, but no specific retention of any individual bile acid was observed. This observation is in contrast with Hylemon et al. (37), who found $20 \%$ of total bile acids to be associated with the cells after $24 \mathrm{~h}$. In human hepatocyte monolayer cultures, in which the effect of ketoconazole on bile acid synthesis was measured from 42 to $66 \mathrm{~h}$ after cell seeding, intracellular bile acids comprised $15 \%$ of total bile acids. A similar value was observed by us with rat hepatocytes 48 to $72 \mathrm{~h}$ in culture (data not shown) and by others (20). This finding indicates that intracellular concentrations of bile acids in hepatocytes decrease with time.

The high amount of bile acids present in the hepatocytes during the initial $24 \mathrm{~h}$ may be the result of an impaired excretion or an increased cellular uptake by the rat hepatocytes. Cultured hepatocytes are able to accumulate high intracellular concentrations of bile acids from the medium $(25,44)$. It is interesting that in presence of $20 \mu \mathrm{M}$ ketoconazole the cell-associated bile acids were significantly lower than in control incubations without the drug. It is tempting to speculate that uptake of bile acids at this concentration of ketoconazole is impaired due to changes of the cell membrane, provoked either by a direct interaction of ketoconazole with membrane lipids or indirectly via the effect of increased lanosterol on membrane and cell functions $(3,45)$.

This paper demonstrates for the first time that human hepatocytes in monolayer culture synthesize cholic and chenodeoxycholic acid. Since we show results from only one hepatocyte isolation, due to the limited availability of human liver, no conclusions should be drawn concerning the absolute synthesis rate of these bile acids. However, it is obvious from this experiment that ketoconazole blocks bile acid synthesis in human hepatocytes in a similar way as observed with rat hepatocytes.

Production of bile acids was inhibited in monolayer cultures of rat and human hepatocytes (Fig. 2 and 3, $I_{50}$ was $5 \mu \mathrm{g} / \mathrm{ml}$ and $0.5 \mu \mathrm{g} / \mathrm{ml}$, respectively), at concentrations within the therapeutic plasma level of the drug $(2-20 \mu \mathrm{g} / \mathrm{ml})$ used in patients (46). These $I_{50}$-values for bile acid synthesis in hepatocytes are of a same magnitude as concentrations inhibiting $50 \%$ corticosterone production in rat adrenal cells (10) and 25-hydroxy-vitamin D24-hydroxylase in pig kidney cells (11).

In agreement with others (37) we showed that $\left[4-{ }^{14} \mathrm{C}\right] 7 \alpha-$ hydroxycholesterol is converted to bile acids (Table I). Since this conversion was almost complete and not blocked by ketoconazole, this is direct evidence that inhibition of bile acid synthesis happened at the cholesterol $7 \alpha$-hydroxylase enzyme. No evidence was obtained that other enzymes in bile acid synthesis pathway, i.e., the $12 \alpha$-hydroxylase and the $6 \beta$-hydroxylase were blocked, since ratios of cholic acid to $\beta$-muricholic acid plus chenodeoxycholic acid, and of chenodeoxycholic acid to $\beta$-muricholic acid did not change with increasing amounts of ketoconazole (Fig. 2). This finding together with results from other studies $(9$, $11,13,45)$ suggests that the effect of ketoconazole on cytochrome P-450-mediated oxidative drug metabolism may be selective. For example, it appears that fungal $14 \alpha$-demethylase is inhibited at a 140 times lower concentration than cholesterol synthesis in human fibroblasts (45) and that testosterone synthesis is blocked selectively at the $\mathrm{C}_{17-20}$-lyase (9).

In vivo experiments in bile-diverted rats confirmed the in vitro observations on inhibition of bile acid synthesis by ketoconazole (Figs. 6 and 7). A dramatic decrease in biliary bile acid excretion to $8 \%$ of the control value was found. This reduction was not due to a blockade of transport of bile acids from liver cells into bile, since excretion of labeled taurocholate in bile was not impaired by the drug.

Another explanation for the declined bile acid excretion in vivo might be a decreased supply of substrate for bile acid synthesis. This possibility had to be considered, since in rats with a chronic bile drainage newly made cholesterol is a major substrate for bile acid formation (47-49) and ketoconazole blocks cholesterol synthesis at the level of $14 \alpha$-demethylation $(2,3)$. On the other hand, it is known that, especially at low bile acid excretion rates, there is a strong correlation between biliary cholesterol and bile acid excretion $(50,51)$, and that cholesterol excretion in the rat does not critically depend on the rate of hepatic cholesterogenesis (52). In addition, we demonstrated that conversion of labeled cholesterol into bile acids is almost complete and inhibited by ketoconazole (Fig. 7 and Table II), indicating that bile acid production is blocked in vivo. The impaired biliary cholesterol output, therefore, is probably secondary to a decreased biliary bile acid excretion.

The $K_{\mathrm{i}}$ of cholesterol $7 \alpha$-hydroxylase for ketoconazole is considerably lower than the $K_{\mathrm{i}}$-value found with metyrapone $(0.55 \mathrm{mM})$, another noncompetitive inhibitor of cholesterol $7 \alpha$ - 
hydroxylase (53). Metyrapone is a drug with a cytochrome P450 blocking activity, used to treat hyperadrenocorticosteroidism. Since it has been suggested to exploit ketoconazole for a similar purpose $(10,11)$, this difference in potency could mean that ketoconazole is a preferable alternative in this treatment.

In summary, the data presented in this paper indicate that ketoconazole very effectively inhibits bile acid synthesis in vivo and in vitro not merely by blocking cholesterogenesis (2-5), but by a direct effect on the regulatory step in the catabolism of cholesterol to bile acids, cholesterol $7 \alpha$-hydroxylase. In the light of the inhibited cholesterogenesis and bile acid synthesis, it would be interesting to determine the effect of ketoconazole on biliary excretion of bile acids and lipids and on size of the bile acid pool and bile composition in humans treated with this drug. Longterm treatment of patients with ketoconazole may lead to a reduced bile acid pool size, resulting in an impaired absorption of lipid-soluble nutrients, e.g., vitamins $\mathrm{A}, \mathrm{D}, \mathrm{K}$, and $\mathrm{E}$.

The fact that this antimycotic agent strongly blocks bile acid synthesis at concentrations easily achieved in plasma of patients treated for fungal infections $(2-20 \mu \mathrm{g} / \mathrm{ml})(46)$, may be usefully applied in clinical practice, in which it would be desirable to inhibit bile acid synthesis, e.g., intractable pruritus due to cholestasis in primary biliary cirrhosis or with extrahepatic obstruction (28). Furthermore, our finding regarding the actions of ketoconazole on cytochrome P-450-dependent enzymes involved in bile acid synthesis, add evidence to the thesis that ketoconazole is a selective inhibitor of cytochrome P-450-activity $(13,45)$. This information warrants further investigation of the drug in clinical research to detect specific effects on other cytochrome P-450-dependent metabolic pathways.

\section{Acknowledgments}

The authors would like to thank Mrs. C. Horsting-Been and Miss M. Horsting for typing the manuscript.

\section{References}

1. Restrepo, A., D. S. Stevens, and J. P. Utz, editors. 1980. First International Symposium on Ketoconazole. Rev. Infect. Dis. 2:519-562.

2. Miettinen, T. A., and V. V. Valtonen. 1984. Ketoconazole and cholesterol synthesis. Lancet. ii: 1271.

3. Van Den Bossche, H., G. Willemsens, W. Cools, F. Cornelissen, W. F. Lauwers, and J. M. Van Cutsem. 1980. In vitro and in vivo effects of the antimycotic drug ketoconazole on sterol synthesis. Antimicrob. Agents Chemother. 17:922-928.

4. Buttke, T. M., and S. W. Chapman. 1983. Inhibition by ketoconazole of mitogen-induced DNA synthesis and cholesterol biosynthesis in lymphocytes. Antimicrob. Agents Chemother. 24:478-485.

5. Kempen, H. J. M., and L. H. Cohen. 1985. Pharmacological blockade of enzymes involved in cholesterol synthesis. In Cholesterol metabolism in health and disease: Studies in the Netherlands. A. C. Beynen, M. J. H. Geelen, M. B. Katan, and J. A. Schouten, editors. Ponsen and Looijen, Wageningen. 1-7.

6. Rollman, O., S. Jameson, and H. Lithell. 1985. Effects of longterm ketoconazole therapy on serum lipid levels. Eur. J. Clin. Pharmacol. 29:241-245.

7. De Felice, R., D. G. Johnson, and J. N. Galgiani. 1981. Gynecomastia with ketoconazole. Antimicrob. Agents Chemother. 19:10731074.

8. Pont, A., P. L. Williams, S. Azhar, R. E. Reitz. C. Bochra, E. R. Smith, and D. A. Stevens. 1982. Ketoconazole blocks testosterone synthesis. Arch. Intern. Med. 142:2137-2140.
9. Santen, R. J., H. van den Bossche, J. Symoens, J. Brugmans, and D. DeCoster. 1983. Site of action of low dose ketoconazole on androgen biosynthesis in men. J. Clin. Endocrinol. Metab. 57:732-736.

10. Pont, A., P. L. Williams, D. S. Loose, D. Feldman, R. E. Reitz, C. Bochra, and D. S. Stevens. 1982. Ketoconazole blocks adrenal steroid synthesis. Ann. Intern. Med. 97:370-372.

11. Loose, D. S., P. B. Kan, M. A. Hirst, R. A. Marcus, and D. Feldman. 1983. Ketoconazole blocks adrenal steroidogenesis by inhibiting cytochrome P450-dependent enzymes. J. Clin. Invest. 71:1495-1499.

12. Sheets, J. J., and J. I. Mason. 1984. Ketoconazole: A potent inhibitor of cytochrome P450-dependent drug metabolism in rat liver. Drug Metab. Dispos. 12:603-606.

13. Meredith, C. G., A. L. Maldonado, and K. V. Speeg, Jr. 1985. The effect of ketoconazole on hepatic oxidative drug metabolism in the rat in vivo and in vitro. Drug Metab. Dispos. 13:156-162.

14. Brown, M. W., A. L. Maldonado, C. G. Meredith, and K. V. Speeg, Jr. 1985. Effect of ketoconazole on hepatic oxidative drug metabolism. Clin. Pharmacol. Ther. 37:290-297.

15. Boström, H., and K. Wikvall. 1982. Hydroxylations in biosynthesis of bile acids. Isolation of subfractions with different substrate specificity from cytochrome P450 LM 4 . J. Biol. Chem. 257:11755-11759.

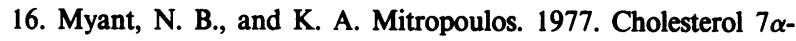
hydroxylase. J. Lipid Res. 18:135-153.

17. Vonk, R. J., A. B. D. van Doorn, and J. H. Strubbe. 1978. Bile secretion and bile composition in the freely moving, unanaesthetized rat with a permanent biliary drainage: influence of food intake on bile flow. Clin. Sci. Mol. Med. 55:253-259.

18. Kuipers, F., R. Havinga, H. Bosschieter, G. P. Toorop, F. R. Hindriks, and R. J. Vonk. 1985. Enterohepatic circulation in the rat. Gastroenterology. 88:403-411.

19. Bligh, E. G., and W. J. Dyer. 1959. A rapid method of total lipid extraction and purification. Can. J. Biochem. Biophys. 37:911-917.

20. Davis, R. A., P. M. Hyde, J. W. Kwan, M. Malone-McNeal, and J. Archambault-Schexnayder. 1983 . Bile acid secretion by cultured rat hepatocytes. Regulation by cholesterol availability. J. Biol. Chem. 258: 3661-3667.

21. Princen, H. M. G., H. J. Moshage, H. J. W. De Haard, P. J. L. Van Gemert, and S. H. Yap. 1984. The influence of glucocorticoid on the fibrinogen messenger RNA content of rat liver in vivo and in hepatocyte suspension culture. Biochem. J. 220:631-637.

22. Williams, G. M., and J. M. Gunn. 1974. Long-term cell culture of adult rat liver epithelial cells. Exp. Cell Res. 89:139-142.

23. Bergmeyer, H. U., and E. Bernt. 1970. Lactat-Dehydrogenase. UV-Test mit Pyruvat und NADH. In Methoden der enzymatische Analyse. H. U. Bergmeyer, editor. Verlag Chemie, Weinheim/Bergstrom. 533-538 pp.

24. Jauregui, H. O., N. T. Hayner, J. L. Driscoll, R. Williams-Holland, M. H. Lipsky, and P. M. Galleti. 1981. Trypan blue dye uptake and lactate dehydrogenase in adult rat hepatocytes. Freshly isolated cells, cell suspensions, and primary monolayer cultures. In Vitro. 17:1100-1110.

25. Scharschmidt, B. F., and J. E. Stephens. 1981. Transport of sodium, chloride, and taurocholate by cultured rat hepatocytes. Proc. Natl. Acad. Sci. USA. 78:986-990.

26. Sprengers, E. D., H. M. G. Princen, T. Kooistra, and V. W. M. van Hinsbergh. 1985. Inhibition of plasminogen activators by conditioned medium of human hepatocytes and hepatoma cell line Hep G2. J. Lab. Clin. Med. 105:751-758.

27. Kempen, H. J. M., M. P. M. Vos-Van Holstein, and J. De Lange. 1982. Bile acids and lipids in isolated rat hepatocytes: content, synthesis, and release, as affected by cholestyramine treatment of the donor rats. J. Lipid Res. 23:823-830.

28. Carey, J. B., Jr. 1973. Bile salt metabolism in man. In The Bile Acids. P. P. Nair and D. Kritchevsky, editors. Plenum Publishing Corp., New York. 2:55-82.

29. Swell, L., J. Gustafsson, C. G. Schwartz, L. G. Halloran, H. Danielsson, and Z. R. Vlahcevic. 1980. An in vivo evaluation of the 
quantitative significance of several potential pathways to cholic and chenodeoxycholic acids from cholesterol in man. J. Lipid Res. 21:455-466.

30. Lowry, O. H., N. J. Rosebrough, A. L. Farr, and R. J. Randall. 1951. Protein measurement with the Folin phenol reagent. J. Biol. Chem. 193:265-275.

31. Gamble, W., M. Vaughan, M. S. Kruth, and J. Avigan. 1978. Procedure for determination of free and total cholesterol in micro- or nanogram amounts suitable for studies with cultured cells. J. Lipid Res. 19:1068-1071.

32. Goodwin, C. D., B. W. Cooper, and S. Margolis. 1982. Rat liver cholesterol $7 \alpha$-hydroxylase. Modulation of enzyme activity by changes in phosphorylation state. J. Biol. Chem. 257:4469-4472.

33. Steffens, A. B. 1969. A method for frequent sampling of blood and continuous infusion of fluids in the rat without disturbing the animal. Physiol. Behav. 4:833-836.

34. Ayaki, Y., T. Tsuma-Date, S. Endo, and M. Ogura. 1981. Role of endogenous and exogenous cholesterol in liver as the precursor for bile acids in rats. Steroids. 38:495-509.

35. Snedecor, G. W., and W. G. Cochran. 1967. Statistical Methods. The Iowa State University Press, Ames, Iowa. Sixth ed. 91-119.

36. Shefer, S., S. Hauser, I. Bekersky, and E. H. Mosbach. 1970 Biochemical site of regulation of bile acid biosynthesis in the rat. J. Lipid Res. 11:404-411.

37. Hylemon, P. B., E. C. Gurley, W. M. Kubaska, T. R. Whitehead, P. S. Guzelian, and Z. R. Vlahcevic. 1985 . Suitability of primary monolayer cultures of adult rat hepatocytes for studies of cholesterol and bile acid metabolism. J. Biol. Chem. 260:1015-1019.

38. Greim, H., D. Trülzsch, J. Roboz, K. Dressler, P. Czygan, F. Hütterer, F. Schaffner, and H. Popper. 1972. Mechanism of cholestasis. 5. Bile acids in normal rat livers and in those after bile duct ligation. Gastroenterology. 63:837-845.

39. Cronholm, T., K. Einarsson, and J. A. Gustafsson. 1974. Changes in in vivo metabolism of bile acids in rat after treatment with phenobarbital. Lipids. 9:844-849.

40. Matschiner, J. T., T. A. Mahowald, W. H. Elliott, E. A. Doisy, Jr., S. L. Hsia, and E. A. Doisy. 1957. Bile acids. I. Two new bile acids from rat bile. J. Biol. Chem. 225:771-779.

41. Kempen, H. J., M. Vos-van Holstein, and J. de Lange. 1983. Bile acids and lipids in isolated rat hepatocytes. II. Source of cholesterol used for bile acid formation, estimated by incorporation of tritium from tritiated water, and by the effect of ML-236B. J. Lipid Res. 24:316-323.
42. Ford, R. P., K. M. Botham, K. E. Suckling, and G. S. Boyd. 1985. Characterisation of rat hepatocyte monolayers for investigation of the metabolism of bile salts. Biochim. Biophys. Acta. 836:185-191.

43. Danielsson, H. 1973. Mechanisms of bile acid biosynthesis. In The Bile Acids. P. P. Nair, and D. Kritschevsky, editors. Plenum Publishing Corp., New York. 2:1-32.

44. Schwartz, L. P., R. Burr, M. Schwenk, E. Pfaff, and H. Greim. 1975. Uptake of taurocholic acid into isolated rat liver cells. Eur. J. Biochem. 55:617-623.

45. Van den Bossche, H. 1985. Biochemical targets for antifungal azole derivatives: Hypothesis on the mode of action. In Current Topics in Medical Mycology. M. R. McGinnis, editor. Springer-Verlag, New York, Berlin. 313-351.

46. Brass, C., J. N. Galgiani, T. F. Blaschke, R. De Felice, R. A. O'Reilly, and D. A. Stevens. 1982. Disposition of ketoconazole, an oral antifungal, in man. Antimicrob. Agents Chemother. 21:151-158.

47. Björkhem, I., and A. Lewenhaupt. 1979. Preferential utilization of newly-synthesized cholesterol as a substrate for bile acid biosynthesis. An in vivo study using ${ }^{18} \mathrm{O}_{2}$-inhalation technique. J. Biol. Chem. 254: 5252-5256.

48. Turley, S. D., and J. M. Dietschy. 1981. The contribution of newly synthesized cholesterol to biliary cholesterol in the rat. J. Biol. Chem. 256:2438-2446.

49. Kempen, H. J. M., J. de Lange, M. P. M. Vos-van Holstein, P. van Wachem, R. Havinga, and R. J. Vonk. 1984. Effect of ML-236B (compactin) on biliary excretion of bile salts and lipids, and on bile flow, in the rat. Biochim. Biophys. Acta. 794:435-443.

50. Swell, L., C. Entenman, G. F. Leong, and R. J. Holloway. 1968. Bile acids and lipid metabolism. IV. Influence of bile acids on biliary and liver organelle phospholipids and cholesterol. Am. J. Physiol. 215: 1390-1396.

51. Hardison, W. G. M., and J. T. Apter. 1972. Micellar theory of biliary cholesterol excretion. Am. J. Physiol. 222:61-67.

52. Turley, S. D., and J. M. Dietschy. 1979. Regulation of biliary cholesterol output in the rat: dissociation from the rate of hepatic cholesterol synthesis, the size of the hepatic cholesteryl ester pool, and the hepatic uptake of chylomicron cholesterol. J. Lipid Res. 20:923-934.

53. Schwartz, M. A., and S. Margolis. 1983. Effects of drugs and sterols on cholesterol $7 \alpha$-hydroxylase activity in rat liver microsomes. $J$. Lipid Res. 24:28-33. 